\title{
Community Engagement to Increase Physical Activity During the Covid-19 Pandemic
}

\author{
Dede Rahman ${ }^{1}$ Riska Devi Kurniawati ${ }^{2,}$ Nanda Agil Bagus Wicaksono ${ }^{3,}$ \\ Muhammad Maulana Yossyan Fachrozi ${ }^{4}$, Yetty Septiani Mustar ${ }^{5^{*}}$
}

\author{
${ }_{1,2,3,4,5}$ Department of Health Education and Recreation, Universitas Negeri Surabaya, Surabaya, Indonesia \\ "Corresponding author.Email: yettymustar@unesa.ac.id
}

\begin{abstract}
It is widely known that physical activity can improve quality of life and health. In addition, regular physical activity is also associated with the improvement of fitness and immunity. This community service activity aims to educate the community of Dusun Wangun about the importance of physical activity during the COVID-19 pandemic to increase immunity, maintain fitness, and introduce some sports that are not popular yet in remote areas villages. The method used in this community service activity is the Participatory Rural Appraisal (PRA) method. These community services results showed that the entire series of activities is carried out very well; this can be seen from the community's enthusiasm during educational activities, socialization of new sports, and practical implementation. Additionally, in order to support the sustainability of the program to increase immunity, fitness, and public health in the wangun village, the society of Wangun is committed to implementing a physical activity program, which is carried out twice a week in the afternoon for 60-90 minutes coordinated by village apparatus and youth organizations (Karang Taruna).
\end{abstract}

Keywords: Physical activity, Immunity, Education, Community services

\section{INTRODUCTION}

In December 2019, an outbreak of Severe Acute Respiratory Syndrome Coronavirus 2 (SARS-CoV-2), also known as COVID-19, was detected, which rapidly spread and infected more than 14 million people [1]. Covid-19 has implications for all aspects of people's lives, including their mental and physical health [2], and is also considered a global health threat that significantly impacts the global economic crisis [3]-[5].

The COVID-19 pandemic in Indonesia has not only impacted the community's economy. Still, it has also become a turning point for the Indonesian people to prioritize various preventive efforts to maintain their health and physical fitness. This health priority is aligned with the government's strategic plan in the National Long-Term Development Plan (RPJPN) 2019-2025 regarding the priority of promotive and preventive efforts, including increasing health promotion, community empowerment, developing national health insurance, meeting the community in accessing quality basic health services, and referrals for mothers, infants, toddlers, adolescents, productive ages, and the elderly
[6]. Maintaining immunity during a pandemic is very important [7]. Regular physical activity is essential for increasing immunity as the body's defense against infection [8]-[12], which will later support a person's fitness status [13]-[15]. Physical activity also helps individuals become more resilient during the pandemic, both mentally and physically [16], prevent respiratory diseases, and protect against bacteria and viruses infection [17].

The World Health Organization (WHO) recommends physical activity for adults at least 150 minutes/week with moderate intensity [18]. Other researchers also proved that moderate-intensity physical activity positively affects the immune system [19]. Therefore, the community needs to carry out the physical activity during the pandemic, especially those with comorbidities, because they are prone to contracting the disease [20].

During the social restriction period, the level of physical activity of the community has decreased significantly with a concurrent increase in sedentary behavior. Physical inactivity is closely related to increased risk of diseases such as depression [21], cancer, and type 2 diabetes [22], to death [23]. In addition, the 
current problem is a lack of public awareness about the importance of physical activity and even a misunderstanding of the correct model of physical activity to increase the body's immunity.

Based on surveys and interviews with several communities in Dusun Wangun, Daliwangun Village found that residents were less interested in physical activity. Residents who do not like to do physical activities are motivated by a lack of understanding of the importance of sports activities for health. Residents still consider sports activities only in the scope of increasing sports achievement. It is essential to do physical activity [24]-[26] and reduce sedentary behavior [27], [28] during the COVID-19 pandemic. Referring to these problems, it is imperative to develop and empower the resident of Wangun to be actively involved in physical activities to improve the body's immune system and physical fitness during the COVID-19 pandemic.

\section{METHODS}

Participatory Rural Appraisal (PRA) is a method used in this community service activity. This program was developed to increase community participation in development. This PRA method allows the community to express and analyze their situation and optimally plan and implement this determination in their village [29]. In PRA, village communities play an active role in mapping social problems and their causes, roadmaps for solving problems and turning them into programs, budget support, and implementation based on community cooperation, self-reliance, and independence. PRA is also an appropriate instrument for assessing community needs at the local level [30]. The partners in this community service activity are residents of Wangun village. They are fully involved in implementing activities, starting from coordinating, preparing, providing for the implementation of activities, participating, and monitoring and evaluating the success of this activity with enthusiasm.

The method of implementing this community service activity goes through several stages, including preparation and survey to the location of service, problem identification, development strategy, program piloting, coordination with village officials and youth organizations in Wangun village, preparation and provision of activity facilities, implementation of activities, and monitoring and evaluation of community service activities. The partners in this community service activity are residents of Wangun village. They are fully involved in implementing activities, starting from coordinating, preparing, and providing for the implementation of activities and participating in the success of this activity with enthusiasm.

This community service in Wangun Village, Lamongan Regency, was conducted for two days. On October 30, 2020 , the first day was held at $15.30 \mathrm{WIB}$, explaining the benefits of sports and understanding sports activities during the COVID-19 pandemic by complying with health protocols [31]. Furthermore, the second day was held on October 31,2020 , at 15.30 WIB, inviting the public to practice physical activity and new sports that are not popular yet among society, such as Rugby, fencing, handball, and hockey.

\section{RESULTS AND DISCUSSION}

Physical inactivity is a global problem [32], which impacts the risk of metabolic syndrome disorders and premature death [33], [34]. Since the outbreak of COVID-19, which imposed restrictions, tended to lead to a decrease in physical activity levels [35]. Factors that influence physical activity involvement include individual psychological factors, including selfconfidence [36], while social and environmental factors include emotional and logistical support [36].

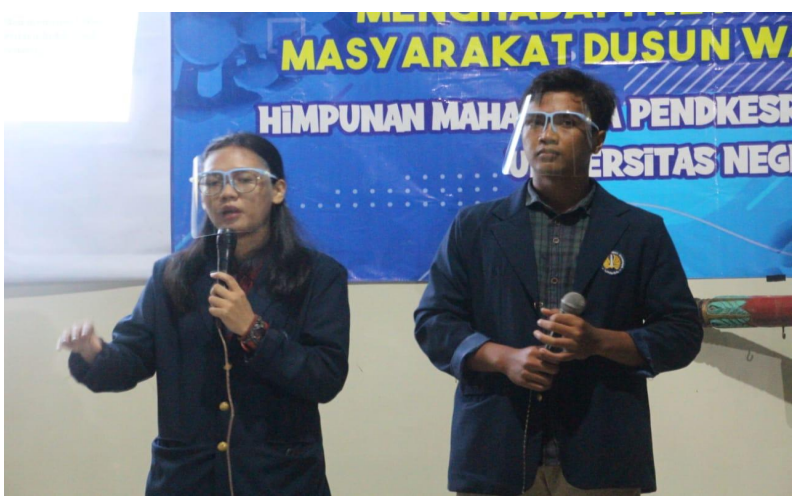

Figure 1 Educational activities with the residents of Wangun village

Community service activities on the first day were educating the public about maintaining fitness, body immunity, increasing immunity during the pandemic through physical activity during the COVID-19 pandemic, and new sports. Maintaining regular physical activity is a crucial component of a healthy lifestyle. Therefore, it is recommended to remain active in sports or doing aerobic exercise and moderate-intensity strength training [37]. In addition, the benefits of physical activity, if done on a scheduled, regular basis, with the appropriate intensity and type, will increase the body's immunity [38], [39].

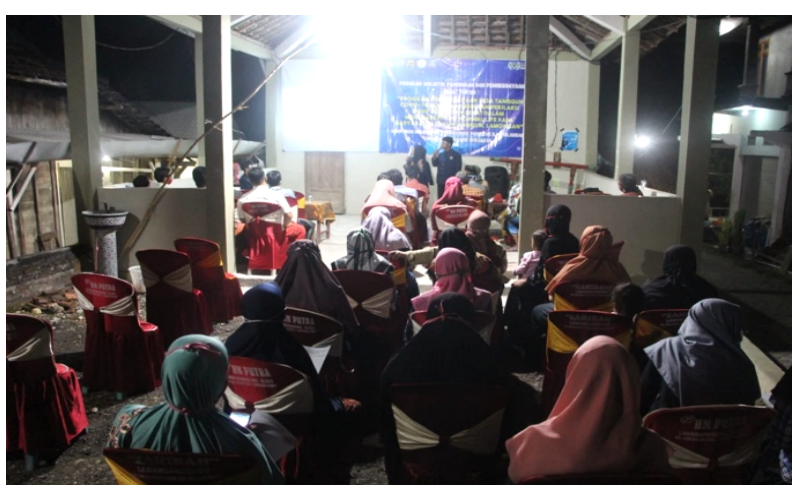

Figure 2 The enthusiasm of Wangun Village residents in receiving materials 
In implementing this educational activity, the community service team also involves youth groups, commonly called "karang taruna," composing ideas that will later support the sustainability of the community service program. The principle of delivering material with an adaptable method is fundamental [40]. Thus, to facilitate people to understand our educational program, the material delivery is conducted according to the conditions and culture in Wangun village.

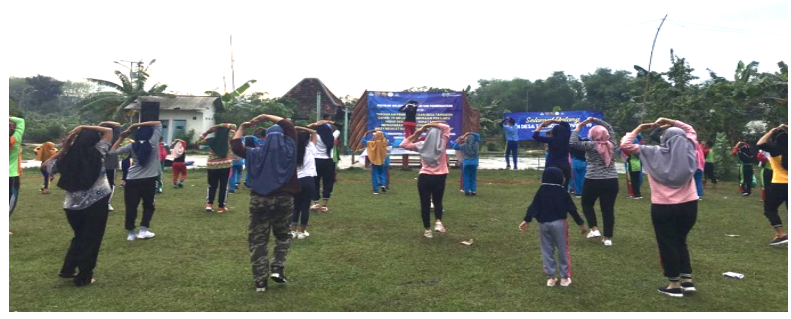

Figure 3 The implementation of physical activity with the residents of Wangun village

Furthermore, the community service activities team conducted physical activity programs prepared with the youth organizations on the second day. This program is carried out to immediately practice various physical activities and sports that can increase the residents' knowledge of Wangun village. Exercising during a pandemic is not only beneficial for physical fitness but is also one of the most effective ways to boost the immune system [10], [41], [42].

The implementation of joint sports activities begins with gymnastics with the residents, then continues with practicing together other sports or new sports that the residents do not yet know, including Rugby, handball, fencing, and hockey carried out in groups. The provision of sports is carried out so that residents get new experiences, do not feel bored in carrying out sports activities, and directly provide benefits to fitness, increasing endurance, cooperation, and stamina.

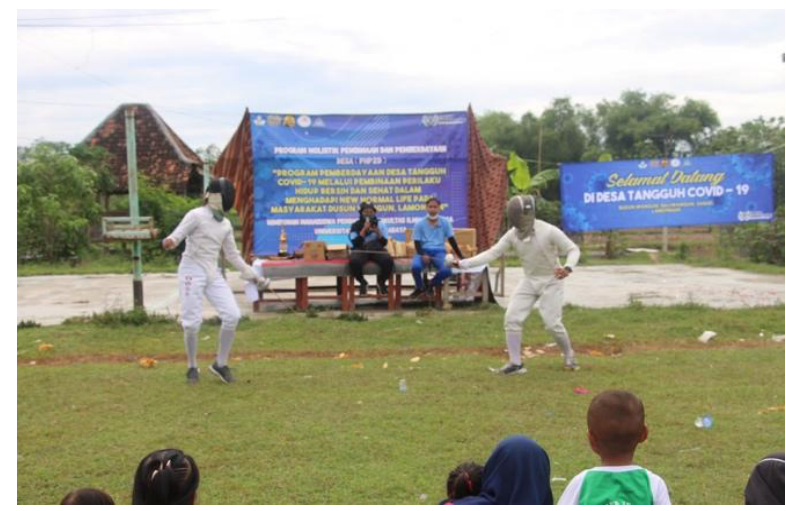

Figure 4 Introduction of fencing to Wangun residents
This activity was viral among residents. A total of 62 people participated in this activity, classifying 20 children, 23 teenagers, ten older adults, and nine elderly representatives from each local area. This activity is hoped to trigger residents' enthusiasm to conduct physical activities during the COVID-19 pandemic.

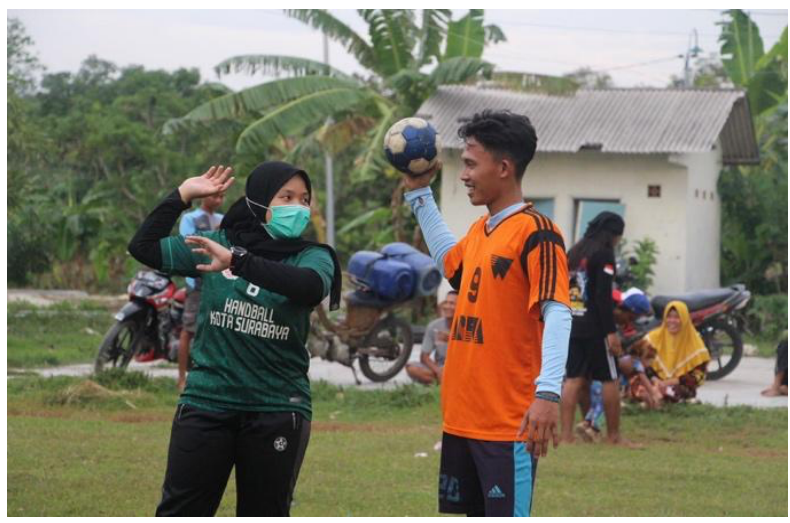

Figure 5 Introduction of handball

In the beginning, it was difficult for residents to practice this new sport, such as passing the ball in Rugby and hockey and holding the stick. However, residents are pleased to do this sporting activity because we do not implement the game rules that the community should carry out. In this activity, the community seemed more enthusiastic about implementing this new sport; even children and parents respond positively by taking turns being a player in practicing this new sport.

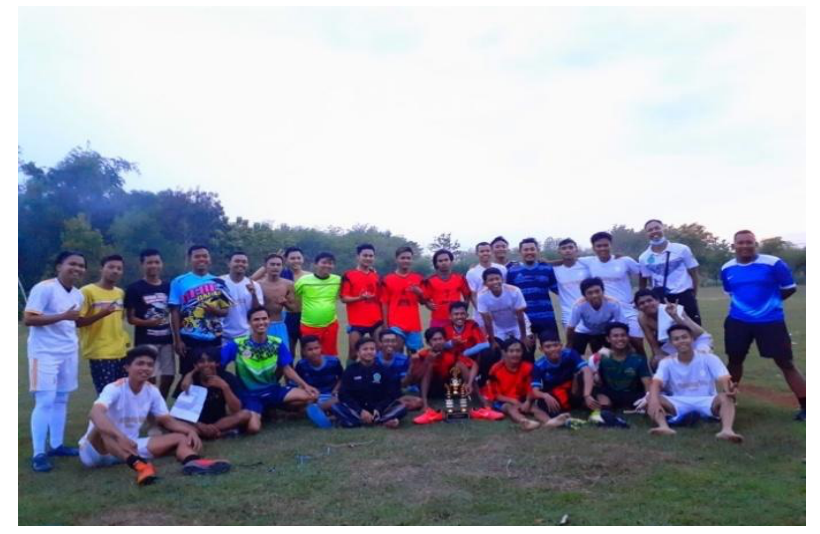

Figure 6 The community service team and youth organizations of Wangun village

Community service activities given to residents were prioritized how sports are enjoyable to carry out so that later the community will continue conducting sports programs prepared. The enthusiasm of the residents of Wangun village exceeded the team's expectations, so this program had a positive impact on the residents. This activity is in line with the service activities conducted by Mustar et al. [43], which showed that fostering students' active participation in improving their fitness and health prioritized more varied, and enjoyable sports activities. Involving youth organizations is also an essential strategy 
in implementing this activity because youth organizations can invite children, other youth, parents, and the elderly to implement the prepared sports program.

At the end of the activity, the community service team evaluated the residents by opening a discussion or question and answer session to find out the progress of community understanding and the community's commitment to stay active in exercising to stay fit, as well as an effort to increase immunity during the pandemic. The residents of Wangun village also announced that the material provided by our team was well organized, and the most important thing was that it was easy to understand by the community because it was accompanied by a form of implementation or practice to conduct sports activity directly. Additionally, village officials also committed that this sport was used as one of the routine programs in Wangun village.

\section{CONCLUSIONS}

The education program for the community to maintain fitness and increase body immunity through physical activity during the pandemic was well implemented, which was shown by the high participation and interest of the Wangun village residents both in socialization activities and practices to conduct sports directly. Additionally, based on the monitoring results two months after the programs showed that a routine exercise program had been arranged two times a week in the afternoon for 60-90 minutes, coordinated by the youth organization in Wangun village. Supporting village officials is essential in monitoring and evaluating the implementation of a sustainable sports activity program.

\section{AUTHORS' CONTRIBUTIONS}

The first author drafted and prepared the manuscript design; the second author conducted data collection; the third author conducted data analysis; the fourth author drafted the manuscript; the fifth author provided direction, adjusted the end of the manuscript, and reviewed the manuscript

\section{ACKNOWLEDGMENTS}

The author would like to thank the Universitas Negeri Surabaya and the Directorate General of Learning and Student Affairs of the Ministry of Education and Culture of the Republic of Indonesia for their guidance, assistance, and funding of activities through the Holistic Village Development and Empowerment Program (PHP2D).

\section{REFERENCES}

[1] J. Liu et al., "Longitudinal characteristics of lymphocyte responses and cytokine profiles in the peripheral blood of SARS-CoV-2 infected patients," EBioMedicine, vol. 55, p. 102763, May 2020, doi: 10.1016/j.ebiom.2020.102763.
[2] E. A. Holmes et al., "Multidisciplinary research priorities for the COVID-19 pandemic: a call for action for mental health science," Lancet Psychiatry, vol. 7, no. 6, pp. 547-560, Jun. 2020, doi: 10.1016/S2215-0366(20)30168-1.

[3] C. Buzzi et al., "The psycho-social effects of COVID-19 on Italian adolescents' attitudes and behaviors," Ital J Pediatr, vol. 46, no. 1, p. 69, May 2020, doi: 10.1186/s13052-020-00833-4.

[4] G. A. Corbett, S. J. Milne, M. P. Hehir, S. W. Lindow, and M. P. O'connell, "Health anxiety and behavioural changes of pregnant women during the COVID-19 pandemic," Eur J Obstet Gynecol Reprod Biol, vol. 249, pp. 96-97, Jun. 2020, doi: 10.1016/j.ejogrb.2020.04.022.

[5] M. Xiang, Z. Zhang, and K. Kuwahara, "Impact of COVID-19 pandemic on children and adolescents' lifestyle behavior larger than expected," Prog Cardiovasc Dis, vol. 63, no. 4, pp. 531-532, Aug. 2020, doi: 10.1016/j.pcad.2020.04.013.

[6] W. J. . Ilham; Munar, Hendri; Saputra, Endarman; Oktadinata, Alex; Daya, "Cerdas Sifa, Edisi 1 No.2.Desember 2018," Cerdas Sifa, no. 2, pp. 7077, 2018.

[7] Y. Suciliyana and W. Widyatuti, "Physical Exercise to Improve Immunity During the Pandemic Covid19," Proceedings of the International Conference on Nursing and Health Sciences, vol. 2, no. 1, Art. no. 1, May 2021.

[8] M. Á. Rodríguez, I. Crespo, and H. Olmedillas, "Exercising in times of COVID-19: what do experts recommend doing within four walls?," Revista Espanola de Cardiologia, 2020, doi: 10.1016/j.recesp.2020.04.002.

[9] M. Narici et al., "Impact of sedentarism due to the COVID-19 home confinement on neuromuscular, cardiovascular and metabolic health: Physiological and pathophysiological implications and recommendations for physical and nutritional countermeasures," European Journal of Sport Science, 2020, doi: 10.1080/17461391.2020.1761076.

[10] C. G. Leandro, W. T. Ferreira E Silva, and A. E. Lima-Silva, "Covid-19 and Exercise-Induced Immunomodulation," NeuroImmunoModulation. 2020. doi: 10.1159/000508951.

[11] M. A. Chowdhury, N. Hossain, M. A. Kashem, M. A. Shahid, and A. Alam, "Immune response in COVID-19: A review," Journal of Infection and Public Health. $2020 . \quad$ doi: 10.1016/j.jiph.2020.07.001.

[12] F. Taghizadeh-Hesary and H. Akbari, "The powerful immune system against powerful COVID19: A hypothesis," Medical Hypotheses, 2020, doi: 10.1016/j.mehy.2020.109762.

[13] D. R. Laddu, C. J. Lavie, S. A. Phillips, and R. Arena, "Physical activity for immunity protection: Inoculating populations with healthy living medicine in preparation for the next pandemic," 
Progress in Cardiovascular Diseases. 2020. doi: 10.1016/j.pcad.2020.04.006.

[14] D. da L. Scheffer and A. Latini, "Exercise-induced immune system response: Anti-inflammatory status on peripheral and central organs," Biochim Biophys Acta Mol Basis Dis, vol. 1866, no. 10, p. 165823, Oct. 2020, doi: 10.1016/j.bbadis.2020.165823.

[15] H. W. Kohl and H. D. Cook, "Educating the Student Body: Taking Physical Activity and Physical Education to School," 2013, Accessed: Sep. 17, 2021. [Online]. Available: http:/www.ncbi.nlm.nih.gov/books/NBK201500/

[16] S. Amatriain-Fernández, E. S. Murillo-Rodríguez, T. Gronwald, S. Machado, and H. Budde, "Benefits of physical activity and physical exercise in the time of pandemic.," Psychological Trauma: Theory, Research, Practice, and Policy, vol. 12, no. S1, p. S264, 2020, doi: 10.1037/tra0000643.

[17] D. C. Nieman, "Coronavirus disease-2019: A tocsin to our aging, unfit, corpulent, and immunodeficient society | Elsevier Enhanced Reader," Journal of sport and health science, vol. 9, pp. 293-301, 2020, doi: 10.1016/j.jshs.2020.05.001.

[18] World Health Organization, Global status report on the public health response to dementia. Geneva: World Health Organization, 2010. Accessed: Sep. 17, 2021. [Online]. Available: https://apps.who.int/iris/handle/10665/344701

[19] M. A. P. D. Kiss, M. T. S. Bohme, A. C. Mansoldo, E. Degaki, and M. Regazzini, "Desempenho e talento esportivos," Revista Paulista de Educação Física, vol. 18, no. esp., pp. 89-100, 2004.

[20] M. J. Ferreira, M. C. Irigoyen, F. ConsolimColombo, J. F. K. Saraiva, and K. D. Angelis, "Physically Active Lifestyle as an Approach to Confronting COVID-19," Arq Bras Cardiol, vol. 114, no. 4, pp. 601-602, Apr. 2020, doi: $10.36660 /$ abc. 20200235 .

[21] H. Huang et al., "COVID-19: A Call for Physical Scientists and Engineers," ACS Nano, vol. 14, no. 4 , pp. 3747-3754, Apr. 2020, doi: 10.1021/acsnano.0c02618.

[22] R. Patterson et al., "Sedentary behaviour and risk of all-cause, cardiovascular and cancer mortality, and incident type 2 diabetes: a systematic review and dose response meta-analysis," Eur J Epidemiol, vol. 33, no. 9, pp. 811-829, Sep. 2018, doi: 10.1007/s10654-018-0380-1.

[23] E. Stamatakis, J. Gale, A. Bauman, U. Ekelund, M. Hamer, and D. Ding, "Sitting Time, Physical Activity, and Risk of Mortality in Adults," $\mathrm{J} \mathrm{Am}$ Coll Cardiol, vol. 73, no. 16, pp. 2062-2072, Apr. 2019, doi: 10.1016/j.jacc.2019.02.031.

[24] S. A. Saputra, "Menjaga Imunitas dan Kesehatan Tubuh melalui Olahraga yang Efektif," Prosiding Seminar Nasional Pendidikan STKIP Kusuma Negara II, 2020.

[25] D. A. W. Setyaningrum, "Pentingnya olahraga selama pandemi COVID-19," Jurnal Biomedika dan Kesehatan, 2020,

doi:

10.18051/jbiomedkes.2020.v3.166-168.

[26] Yuliana, "Olahraga yang Aman di Masa Pandemi COVID-19 untuk Meningkatkan Imunitas Tubuh," Jurnal Bali Membangun Bali, 2020, doi: 10.51172/jbmb.v1i2.112.

[27] C. Zheng, W. Y. Huang, S. Sheridan, C. H.-P. Sit, X.-K. Chen, and S. H.-S. Wong, "COVID-19 Pandemic Brings a Sedentary Lifestyle in Young Adults: A Cross-Sectional and Longitudinal Study," Int J Environ Res Public Health, vol. 17, no. 17, Sep. 2020, doi: 10.3390/ijerph17176035.

[28] S. Stockwell et al., "Changes in physical activity and sedentary behaviours from before to during the COVID-19 pandemic lockdown: a systematic review," BMJ Open Sport Exerc Med, vol. 7, no. 1, p. e000960, Jan. 2021, doi: 10.1136/bmjsem-2020000960.

[29] B. Mikkelsen, Metode penelitian partisipatoris dan upaya pemberdayaan: Panduan bagi praktisi lapangan $=$ Methods for development work and research: a guide for practitioners. Yayasan Pustaka Obor Indonesia, 2011.

[30] J. G. Mueller, I. H. B. Assanou, I. Dan Guimbo, and A. M. Almedom, "Evaluating rapid participatory rural appraisal as an assessment of ethnoecological knowledge and local biodiversity patterns," Conserv Biol, vol. 24, no. 1, pp. 140-150, Feb. 2010, doi: 10.1111/j.1523-1739.2009.01392.x.

[31] Y. E. Nopiyanto, S. Raibowo, T. Sugihartono, and Y. Yarmani, "Pola Hidup Sehat Dengan Olahraga dan Asupan Gizi Untuk Meningkatkan Imun Tubuh Menghadapi Covid-19," Dharma Raflesia : Jurnal Ilmiah Pengembangan dan Penerapan IPTEKS, vol. 18, no. 2, pp. 90-100, 2020, doi: 10.33369/dr.v18i2.13008.

[32] P. Das and R. Horton, "Rethinking our approach to physical activity," Lancet, vol. 380, no. 9838, pp. 189-190, Jul. 2012, doi: 10.1016/S01406736(12)61024-1.

[33] C. L. Edwardson et al., "Association of sedentary behaviour with metabolic syndrome: a metaanalysis," PLoS One, vol. 7, no. 4, p. e34916, 2012, doi: 10.1371/journal.pone.0034916.

[34] M. H. Forouzanfar et al., "Global, regional, and national comparative risk assessment of 79 behavioural, environmental and occupational, and metabolic risks or clusters of risks in 188 countries, 1990-2013: a systematic analysis for the Global Burden of Disease Study 2013," Lancet, vol. 386, no. 10010, pp. 2287-2323, Dec. 2015, doi: 10.1016/S0140-6736(15)00128-2.

[35] P. Chen, L. Mao, G. P. Nassis, P. Harmer, B. E. Ainsworth, and F. Li, "Coronavirus disease (COVID-19): The need to maintain regular physical activity while taking precautions," J Sport Health Sci, vol. 9, no. 2, pp. 103-104, Mar. 2020, doi: 10.1016/j.jshs.2020.02.001.

[36] A. E. Bauman et al., "Correlates of physical activity: why are some people physically active and 
others not?," Lancet, vol. 380, no. 9838, pp. 258271, Jul. 2012, doi: 10.1016/S01406736(12)60735-1.

[37] Y. J. Chan, M. F. Chong, C. L. Law, and D. G. Hassell, "A review on anaerobic-aerobic treatment of industrial and municipal wastewater," Chemical Engineering Journal. 2009. doi: 10.1016/j.cej.2009.06.041.

[38] B. B. Tiksnadi, N. Sylviana, A. I. Cahyadi, and A. C. Undarsa, "Olahraga Rutin untuk Meningkatkan Imunitas Pasien Hipertensi Selama Masa Pandemi COVID-19," Indonesian Journal of Cardiology, vol. 41, no. 2, pp. 112-119, 2020, doi: 10.30701/ijc. 1016.

[39] W. S. Limbong, M. Lyna Girsang, and R. D. Panggabean, "Sosialisasi Gaya Hidup Sehat Pada Masa Pandemi Covid-19 Di Panti Asuhan Talenta Delpita Di Medan," Jurnal Abdimas Mutiara, 2020.

[40] A. Pragholapati, "New Normal 'Indonesia' After Covid-19 Pandemic," vol. 2019, pp. 1-6, 2020, doi: 10.31234/osf.io/7snqb.
[41] A. V. Mattioli, S. Sciomer, C. Cocchi, S. Maffei, and S. Gallina, "Quarantine during COVID-19 outbreak: Changes in diet and physical activity increase the risk of cardiovascular disease," Nutrition, Metabolism and Cardiovascular Diseases. $2020 . \quad$ doi: 10.1016/j.numecd.2020.05.020.

[42] G. Hall, D. R. Laddu, S. A. Phillips, C. J. Lavie, and R. Arena, "A tale of two pandemics: How will COVID-19 and global trends in physical inactivity and sedentary behavior affect one another?," Progress in Cardiovascular Diseases. 2020. doi: 10.1016/j.pcad.2020.04.005.

[43] Y. S. Mustar, I. H. Susanto, A. P. Bakti, and B. Agung, "Pembinaan Partisipasi Aktif Sekolah Dasar dalam Meningkatkan Kebugaran dan Kesehatan Siswa," Jurnal Pengabdian Kepada Masyarakat, vol. 3, no. 1, p. 6, 2020. 